\title{
A brief overview of the capacities of public forest administrations in climate change work in the moist forests countries of Sub-Saharan Africa
}

\author{
${ }^{1}$ Cliff Dlamini, ${ }^{2}$ Larwanou Mahamane, Nguembou Charlemagne ${ }^{3}$ Paxie W Chirwa ${ }^{4}$ \\ ${ }^{1}$ WWF South Africa, c/o Table Mountain Fund, Centre for Biodiversity Conservation, \\ Kirstenbosch National Botanical Gardens, P.O. Box 23273, Claremont, 7735, South Africa. \\ ${ }^{2,3}$ African Forest Forum (AFF), clo World Agroforestry Centre (ICRAF), United Nations \\ Avenue, Gigiri, \\ P.O. Box 30677 - 00100, Nairobi, Kenya. \\ ${ }^{4}$ Forest Science Postgraduate Programme, University of Pretoria, 5-15 Plant Sciences Complex, \\ Pretoria, South Africa
}

\begin{abstract}
The work of Public Forest Administrations (PFAs) has evolved from forest management, to sustainable forest management, to management of forests and woodlands for ecosystem goods and services, to climate change mitigation and adaptation. The objective of this review is to give an overview of the capacities of PFAs in forest-related climate work. Findings have shown that though they still exist under national governments like in the colonial era, in the majority of moist forest countries PFAs have been transformed from mere forest protection and conservation into modern people-centred and participatory approaches. In addition, most countries have lack of trained staff personnel to undertake forest and climate change work. PFAs are under-funded because they are not a top priority in national budgets. In addition there is lack of stakeholder participation, unclear access and equitable benefit sharing, inadequate capacity in estimation and reporting on National GHG inventories, in application of the IPCC GPG.
\end{abstract}

Keywords: Adaptation, Climate Change, Mitigation, Sustainable Forest Management 


\subsection{INTRODUCTION}

\section{Moist Forest Countries in Africa}

Moist forests are predominantly found in West and Central Africa and the principal ecosystem is the Congo Basin. The Congo Basin, sometimes referred to as the Lower Guineo-Congolian forests contains the world's second-largest dense humid tropical forest, surpassed only by the Amazon Basin. It extends from the coast of the Atlantic Ocean in the west to the mountains of the Albertine Rift in the east and spans the equator by nearly 7 degrees north and south (CBFP, 2005, 2006; GEF, 2011). West Africa includes sparsely populated, highly forested countries (e.g. Liberia) and densely populated, forest-poor countries (e.g. Ghana, Togo, and Nigeria). The Congo Basin forests comprise the following countries: Burundi, Cameroon, Central African Republic, Democratic Republic of the Congo, Equatorial Guinea, Gabon, Rwanda and Republic of the Congo. The Congo Basin Forest is one of two remaining regions on Earth that still boast large interconnected tracts of tropical rain forest. According to CBFP $(2005,2006)$ and GEF (2011), the forest harbour the most diverse assemblage of plants and animals in Africa including over 400 mammal species, more than 1,000 bird species, and over 10,000 plant species of which 3,000 are endemic. Considering its sheer size, the Congo Basin Forest serves as a vast carbon sink of global importance for the regulation of the greenhouse gas, carbon dioxide. The Congo Basin forests store approximately 35 billion out of a global total of 290 billion tons of carbon stored in forests. As a result, the Congo basin countries potentially have much to benefit from participating in REDD programs. Its countries are actively engaged in REDD programmes both at a country level and through the regional forest organization COMIFAC. DRC is participating in the Forest Investment Program under the Climate Investment Funds (World Bank, 2012). The forest also plays a vital role in regulating regional and local weather patterns, and ensuring the cycling of water which is critical for a large area of Africa (CBFP, 2005, 2006; GEF, 2011; World Bank, 2012).

In West Africa, conservation initiatives are challenged by increasing population densities, limited conservation capacity and, increasingly, pressure from mining and hydroelectric power developments (FAO, 2005; FAO, 2010, FAO, 2011; FAO, 2012; World Bank, 2012). In addition, high deforestation rates pose a major threat to forests in the region. For instance, the World Bank (2012) reported that Ghana and Nigeria have among the highest deforestation rates of any of the African countries at $-1.89 \%$ and $3.12 \%$ respectively. This is linked to rapid population growth rates, expansion of agricultural land, and also policies related to land tenure, rights to trees of land owners and tenants and to timber revenue collection and distribution systems. However, there are opportunities through the FLEGT (Forest Law Enforcement Governance and Trade) process spearheaded by the EU. The European market demands have helped to promote the sustainable exploitation of the exported timber products in the region (World Bank, 2012). A classical illustration of the negative provisions of the EU policies include the initiatives of provision of conservation to create opportunities to address biodiversity while engaging in large-scale mining or hydro-power development (e.g. the provision for a 
conservation offset under the Bumbuna hydroelectric power plant in Sierra Leone (World Bank, 2012).

The main challenge in Central Africa has been the lack of inter-ministerial coordination resulting in conflicting interests; as has been cases where mining concessions have been allocated on land already allocated for forest concessions (World Bank, 2012). Notwithstanding, the Congo basin countries have a comparative advantage in benefiting from participating in REDD programs because of their active engagement nationally and regionally through the forest organization COMIFAC. For example, countries like DRC are also participating in the Forest Investment Program under the Climate Investment Funds (World Bank, 2012). In order to effectively address REDD, there is also an opportunity to invest outside the forest sector through supporting enhanced agricultural productivity, to reduce the need for extensive "slash and burn" approaches, and in productive fuel-wood and construction wood plantations in the vicinity of the major cities to reduce the pressure on natural forests (World Bank, 2012).

\section{Public Forest Administration in Moist Forest Countries}

Public forest administration (PFAs) in moist forest countries have evolved since the 1900 Convention for the Preservation of Wild Animals, Birds and Fish in Africa. This convention set a framework for the establishment and operation of the earliest PFAs in the Africa sub-region. The 1933 Convention Relative to the Preservation of Fauna and Flora in their Natural State set out guidelines for all PFAs in former British and German colonies including Ghana, Nigeria and Sierra Leon (Kameri-Mbote and Cullet, 1997). Niger, Cote d'Ivoire, Mali, Benin, Guinea and Senegal and other former French colonies only managed to establish their first PFAs in the turn of the century after forestry establishment in France, and these PFAs were customized to suit country-specific needs and priorities. From mid-1940s and early 1960s, PFAs started to address conservation production needs of countries. In meantime, the British Model in Anglophone countries such as Ghana, Nigeria and Sierra Leon was adopted. While the French Model in Francophone countries like Cote d'Ivoire, Togo, Benin, Guinea and Guinea Bissau, Central African Republic, Congo, Democratic Republic of the Congo, Equatorial Guinea, Gabon and Cameroon was adopted. These models were so strong that their legacy still exists in some countries even today (Wily, 2002).

\section{Criteria for sustainability in Public Sector Forestry}

In order to guarantee a future for public sector forestry the following set of criteria may need to be met:

1. Adequate financial support to PFA and how the resources are mobilised and extent to which PFAs are self-supporting:

Formulation and implementation of sustainable financing mechanisms and approaches by PFAs will ensure internal generation of funds for forest management, and fund-raising for external 
funds to support the growth and sustainability of public sector forestry (Dlamini, 2013). An example of moist forest country that has made commendable efforts towards establishment of forest revenue retention schemes is Ghana (FAO, 2011, 2012).

2. Availability of conditions under which public administration earns a surplus from forest management:

Promoting small-scale forest enterprise development for sustainable livelihoods increases economic, social and environmental benefits of natural forests and woodlands. Increased direct use benefits would guarantee enhanced income from forest resources. Small-scale forest enterprise development advocates for sustainable forest resources use, sound land use planning, appropriate land conversions, reduced deforestation and forest degradation, adaptive research, prescribed stocking rates, land reclamation and cultivates the culture of best practice (Dlamini, 2013).

\section{The ability to fully capture the benefits from management of forests:}

The concept of forest valuation or forest ecosystem valuation is not well understood in most countries in SSA, and as such the total value of direct benefits, indirect benefits and intermediate use services of natural forests and woodlands is not reflected in the System of National Accounts (SNA). Realization of the full value forest ecosystem goods and services has a great potential for providing additional sources of funding for the development of the public sector forestry (Hassan et al, 2002; Dlamini, 2007; Dlamini, 2013).

\section{The overall economic viability of public sector forestry institutions:}

Owino and Ndinga (2004) reported that a few forest-rich countries such as the Central Africa Republic (CAR) and Côte d'Ivoire do not only sustain public expenditure from forest revenue but also provide a surplus for other government services. In principle, PFA in such countries should be self-supporting. Good governance and accountability could transform other moist forest countries to have self-sustaining PFAs as well.

The objective of this review is to highlight the public forest administration and its link to climate change work and further synthesize available information on climate change work and identify the capacity available to effectively conduct climate change activities in moist forest countries of Sub-Sahara Africa.

\section{SCOPE OF CLIMATE CHANGE ACTIVITIES}

\section{West Africa}

According to Popoola (2013a), there is no Climate Change section in Benin though per se, there are numerous government agencies engaged in climate change work. In the forestry sector, climate change related work includes reforestation, promotion of income-generation activities, promotion of new technologies, afforestation, promotion of botanical gardens, prevention of disasters. However, resources available for climate change work are not unlimited and financing for such programmes come from international bilateral and multilateral organizations, national 
government, NGOs, faith-based organizations, community-based organizations and the private sector. In Burkina Faso, like in Benin, there is no climate change department. The government policy here is inflexible, especially on access and tenure rights on forest resources, and this makes it extremely difficult for the local communities adjacent to natural forests and woodlands to use these resources for climate change mitigation and adaptation. This implies that there may be no on-going climate change work within the context of forestry. In Cape Verde, the public forestry department operates in a very traditional set-up whereby the conventional roles and responsibilities of a typical colonial forestry department is to manage forests resources, control access and extraction of goods and also implement policy and enforce laws. Not much is being said about climate change work. Gambia has had one of the most innovative and most effective and radical national forest policy and national forestry programmes. The country's forestry department has rolled out programmes that have almost halted deforestation and forest degradation and have introduced the adoption of new technology for energy saving in form of energy saving stoves. Government policy discourages commercial forest harvesting for fuel wood in forest degraded areas. In Ghana, the Environment Protection Agency and the Forestry Commission (within which there is a Climate Change Unit) are responsible for climate change work. However, there are several other agencies working on climate change. Various climate change mitigation and adaptation activities are on-going and there is a massive awareness creation and education about REDD+ initiatives. In Guinea, little is mentioned about climate change work, except that the new public forest administration methods of forest management have adopted the participatory and inclusive approach, where multi-stakeholders participate in policy formulation, development, implementation and monitoring. The military trained forest guards have been changed into new forest agents that are multi-stakeholder focussed. As expected, forest policy and legislation is the responsibility of the national government in Ivory Coast. Though there is no Climate Change Policy in the country there is a REDD+ project through funds from national government, NGOs and multilateral international organizations. The on-going climate change work is funded by the FAO, EU, the ACP Secretariat, AfDB, and others. Several agencies and government departments are involved in climate change work in the country. In Liberia, all forests are government-owned with the implementation of the forest policy also being led by the state government. The PFA is based on the "three Cs": conservation, commercialization and community; and this ensures economic viability, social acceptability and ecological integrity. Whilst there is no climate Change Policy, there is climate change work and numerous agencies have responsibilities to carry out various activities. Main climate change work includes building resilience of communities against coastal erosion and establishment of early climate warning systems. Funding as in other countries in the region comes from national government, NGOs, private sector and international multilateral organizations. Mali signed and ratified the three major UN Conventions, UNCBD, UNCCD and UNFCCC in order to respond to the MDGs but little information is available on on-going climate change work. Nigeria has a fully-fledged national forest policy and a climate change policy. As much as there is a Climate Change section in the Ministry of Environment, a number of agencies and government departments are also involved climate change work. Climate change work includes vulnerability and adaptation, renewable energy, mitigation and greenhouse gas inventory, awareness, education and outreach. Funding sources are mainly international agencies and national government. 


\section{Central Africa and the Congo Basin}

Mvondo (2012) and Donfack (2013) reported that CAR, DRC, Sao Tome and Principe and Chad have managed to prepare their National Action Plans for Adaptation (NAPA) through GEF and UNEP funding. Cameroon, Congo, Gabon and Sao Tome and Principe, are amongst the implementers of the African Adaptation Program (AAP) which is a long-term programme towards building and consolidating their capacities and adaptation and disaster reduction programs. Country-specific adaptation scenarios are presented in Table 1.

According to Donfack (2013), the significant role of forests and associated ecosystems towards climate change mitigation is clearly recognized and hence demonstrated by the post- Kyoto climate change processes, and also with the adoption of the REDD+ mechanism in COP-16 in Cancun. The rates of deforestation and forest degradation in most Central African countries are relatively low compared to their Asian and South America counterparts. Current situation of mitigation programs in targeted countries are summarized in Table 2. Moreover, most countries have already prepared their Readiness Preparation Proposals (R-PP) through their various PFAs and other partners (NGOs, other government departments, international bilateral and multilateral organizations, etc.) and are at different stages (from preparation to validation and acceptance). An overview of the of country status in terms of level of involvement in the REDD+ process indicate that Chad, Sao Tome and Principe and Gabon are at preliminary stages. Meanwhile Equatorial Guinea is at the initial stages of phase one. The Democratic Republic of the Congo, Congo, Cameroon and the Central Africa Republic have advanced to the second phase. 
Table 1: Summary of the current situation of adaptation programs in targeted countries

\begin{tabular}{|c|c|c|c|c|}
\hline \multirow[t]{2}{*}{ Country } & \multicolumn{2}{|c|}{ Forest-climate change projects (Under NAPAs) } & \multicolumn{2}{|c|}{ Other Climate change related projects } \\
\hline & Project & Level of implementation & Project & Level of implementation \\
\hline \multirow[t]{4}{*}{ Cameroon } & & \multirow[t]{4}{*}{ No data } & $\begin{array}{l}\text { African Adaptation Program } \\
\text { (AAP) /UNPD with support from } \\
\text { Japan }\end{array}$ & Under implementation \\
\hline & & & $\begin{array}{l}\text { National action Plan for } \\
\text { Environment (Government funds) }\end{array}$ & Under implementation \\
\hline & & & $\begin{array}{l}\text { National Plan of Action to } \\
\text { Combat Desertification (PAN / } \\
\text { LCD) (Government funds) }\end{array}$ & Under implementation \\
\hline & & & $\begin{array}{l}\text { Support program for the } \\
\text { implementation of integrated and } \\
\text { global approaches to climate } \\
\text { change adaptation (UNDP) }\end{array}$ & $\begin{array}{l}\text { Under implementation, } \\
\text { given support among other } \\
\text { to the elaboration of the } \\
\text { National Adaptation plan } \\
\text { (NAP) for Climate Change }\end{array}$ \\
\hline \multirow[t]{4}{*}{ Congo } & & \multirow[t]{4}{*}{ No data } & $\begin{array}{l}\text { African Adaptation Program } \\
\text { (AAP) /UNPD with support from } \\
\text { japan }\end{array}$ & Under implementation \\
\hline & & & $\begin{array}{l}\text { National Action Plan for the } \\
\text { Environment (PANAE), }\end{array}$ & Under implementation \\
\hline & & & $\begin{array}{l}\text { the National Action Plan for the } \\
\text { Fight against Desertification } \\
\text { (PAN / LCD), }\end{array}$ & Under implementation \\
\hline & & & $\begin{array}{l}\text { National Adaptation plan (NAP) } \\
\text { for Climate Change (UNDP) }\end{array}$ & Under elaboration \\
\hline \multirow[t]{3}{*}{ Gabon } & \multirow{3}{*}{-} & \multirow[t]{3}{*}{ No data } & $\begin{array}{l}\text { African Adaptation Program } \\
\text { (AAP) /UNPD with support from } \\
\text { japan }\end{array}$ & Under implementation \\
\hline & & & NCSA & Under implementation \\
\hline & & & $\begin{array}{l}\text { National Plan of Action for } \\
\text { Environmental Management }\end{array}$ & Under implementation \\
\hline
\end{tabular}




\begin{tabular}{|c|c|c|c|c|}
\hline \multirow[t]{4}{*}{ Country } & \multicolumn{2}{|l|}{ Forest-climate change projects (Under NAPAs) } & \multicolumn{2}{|c|}{ Other Climate change related projects } \\
\hline & Project & Level of implementation & Project & Level of implementation \\
\hline & & & (NAPEM) & \\
\hline & & & $\begin{array}{l}\text { FORINO Project (contribution to } \\
\text { sustainable management of NR }\end{array}$ & Under implementation \\
\hline \multirow[t]{2}{*}{$\begin{array}{l}\text { Equatorial } \\
\text { Guinea }\end{array}$} & & No data & $\begin{array}{l}\text {-National Action Program to } \\
\text { Combat Land degradation and } \\
\text { deforestation PAN/LCD-GE }\end{array}$ & -under implementation \\
\hline & & No data & $\begin{array}{l}\text { Reinforcement of institutional } \\
\text { legal and individual capacities for } \\
\text { sustainable management of Land } \\
\text { and forest (under PAN/LCD with } \\
\text { support from GEF }\end{array}$ & - under implementation \\
\hline \multirow[t]{5}{*}{$\begin{array}{l}\text { Central } \\
\text { Africa } \\
\text { Republic }\end{array}$} & $\begin{array}{l}\text { Reinforcement of community eco development } \\
\text { institutions in the forest sector(source of } \\
\text { funding to identify) }\end{array}$ & Yet to start & $\begin{array}{l}\text { project on response measures and } \\
\text { early warning systems }\end{array}$ & \\
\hline & $\begin{array}{l}\text { Promotion of Urban forestry in Bossangoa } \\
\text { Region (source of funding to identify) }\end{array}$ & Yet to start & $\begin{array}{l}\text { National program for the fight } \\
\text { against Desertification } \\
\text { (PAN/LCD) }\end{array}$ & Under implementation \\
\hline & $\begin{array}{l}\text { Management of native vegetation for the } \\
\text { rehabilitation of degraded pastoral zones at } \\
\text { Bossemptele (support expected from } \\
\text { GEF/UNDP) }\end{array}$ & Yet to start & & \\
\hline & $\begin{array}{l}\text { Community participation for reforestation and } \\
\text { forest management in Ombella M'Poko } \\
\text { location (support expected from GEF/UNDP) }\end{array}$ & Yet to start & & \\
\hline & $\begin{array}{l}\text { Support Program for the Conservation of } \\
\text { Ecosystems of the Congo Basin (PACEBCo), } \\
\text { funded by the AfDB \& ECCAS. }\end{array}$ & Under implementation & & \\
\hline \multirow[t]{2}{*}{$\begin{array}{l}\text { Democratic } \\
\text { Republic of } \\
\text { Congo }\end{array}$} & $\begin{array}{l}\text { Conservation and management of the } \\
\text { biodiversity of Mangrove Marine Park }\end{array}$ & Under implementation & $\begin{array}{l}\text { Environmental National Action } \\
\text { Plan (PNAE) }\end{array}$ & --under implementation \\
\hline & & & $\begin{array}{l}\text { Strategy of Environmental } \\
\text { Capacity building (ANCR) }\end{array}$ & -under implementation \\
\hline
\end{tabular}




\begin{tabular}{|l|l|l|l|l|}
\hline Country & Forest-climate change projects (Under NAPAs) & Level of implementation & Project & Llimate change related projects \\
\cline { 2 - 5 } & Project & & $\begin{array}{l}\text { National scheme for territorial } \\
\text { management }\end{array}$ & -under implementation \\
\hline & & & $\begin{array}{l}\text {-National Action Program to } \\
\text { Combat Land degradation and } \\
\text { deforestation PAN/LCD-GE }\end{array}$ & -under implementation \\
\hline Chad & $\begin{array}{l}\text { Realisation of tools for defence and restoration } \\
\text { of soils, }\end{array}$ & Yet to be funded by GEF & $\begin{array}{l}\text { Amelioration of seasonal } \\
\text { prevision and its integration in the } \\
\text { strategy of monitoring of the } \\
\text { vulnerability }\end{array}$ & Yet to be funded by GEF \\
\cline { 2 - 5 } & Improvement of intercommunity grazing lands & Yet to be funded by GEF & $\begin{array}{l}\text { National observatory on climate } \\
\text { change }\end{array}$ & Yet to be funded by GEF \\
\hline
\end{tabular}

Source: Donfack (2013) 
Table 2: Summary of the current situation of mitigation programs in targeted countries

\begin{tabular}{|c|c|c|c|c|c|}
\hline \multirow[t]{2}{*}{ Country } & \multirow[t]{2}{*}{ R-PP } & \multicolumn{2}{|c|}{ Forest-climate change projects under NAMAS } & \multicolumn{2}{|c|}{ Other climate change related projects } \\
\hline & & Project & $\begin{array}{l}\text { Level of } \\
\text { implementation }\end{array}$ & Project & Level of implementation \\
\hline \multirow[t]{6}{*}{ Cameroon } & \multirow[t]{6}{*}{2012} & $\begin{array}{l}\text { Mount Cameroon Project (REDD in } \\
\text { Biodiversity hotspots under threats) }\end{array}$ & Feasibility study & $\begin{array}{l}\text { Environmental and Forest } \\
\text { sectorial program }\end{array}$ & Under implementation \\
\hline & & $\begin{array}{l}\text { Takamanda Mone project (REDD+ } \\
\text { community management of forest) } \\
\text { (WCS) }\end{array}$ & $\begin{array}{l}\text { Pre identification } \\
\text { phase }\end{array}$ & $\begin{array}{l}\text { Reduction emission from all } \\
\text { land use }\end{array}$ & Under implementation \\
\hline & & $\begin{array}{l}\text { Mbam \& Djerem Project (REDD in a } \\
\text { protected area) (WCS) }\end{array}$ & Starting phase & $\begin{array}{l}\text { REDD Pilot project (GAF- } \\
\text { GA) }\end{array}$ & Terminated \\
\hline & & $\begin{array}{l}\text { Ngoyla-Mintom (REDD in a protected } \\
\text { area) (WWF) }\end{array}$ & $\begin{array}{l}\text { Under } \\
\text { implementation }\end{array}$ & $\begin{array}{l}\text { Research and capacity } \\
\text { building project } \\
\text { (TROPENBOS) }\end{array}$ & Terminated \\
\hline & & $\begin{array}{l}\text { Payment of ecosystems services for } \\
\text { communities (CED) }\end{array}$ & $\begin{array}{l}\text { End of } \\
\text { implementation phase }\end{array}$ & & \\
\hline & & REDD Alert project & Terminated & & \\
\hline \multirow[t]{2}{*}{ Congo } & \multirow[t]{2}{*}{2010} & $\begin{array}{l}\text { REDD Pilot project with WRI } \\
\text { (deforestation, carbon stock analysis, } \\
\text { forest degradation analysis) }\end{array}$ & $\begin{array}{l}\text { Under } \\
\text { implementation since } \\
2010\end{array}$ & & \\
\hline & & $\begin{array}{l}\text { REDD Pilot project with GAF-AG } \\
\text { (Cartography of deforestation, } \\
\text { technology transfer, sensitisation) }\end{array}$ & $\begin{array}{l}\text { Starting } \\
\text { implementation }\end{array}$ & & \\
\hline Gabon & - & & & $\begin{array}{l}\text { Support to sustainable } \\
\text { management of forest } \\
\text { resources (CDFF \& AfDB) }\end{array}$ & 3 years \\
\hline
\end{tabular}




\begin{tabular}{|c|c|c|c|c|c|}
\hline & & & & $\begin{array}{l}\text { Support to sustainable } \\
\text { management of forest } \\
\text { resources (FFEM) }\end{array}$ & \\
\hline & & & & $\begin{array}{l}\text { Development of a system of } \\
\text { national natural resources } \\
\text { inventory (JICA) }\end{array}$ & Starting implementation \\
\hline & & & & $\begin{array}{l}\text { Forestry and environmental } \\
\text { sectorial program (FESP) } \\
\text { (capacity building of } \\
\text { national forest and } \\
\text { environmental services) }\end{array}$ & $\begin{array}{l}\text { Under implementation with } \\
\text { support from various donors }\end{array}$ \\
\hline & & & & National forest action plan & Under implementation \\
\hline $\begin{array}{l}\text { Equatorial } \\
\text { Guinea }\end{array}$ & - & & & $\begin{array}{l}\text { National action plan for } \\
\text { Biodiversity }\end{array}$ & Under implementation \\
\hline \multirow[t]{3}{*}{ CAR } & \multirow[t]{3}{*}{2011} & $\begin{array}{l}\text { Bee-keeping \& reforestation around } \\
\text { Bagandou forest }\end{array}$ & 3 years & & \\
\hline & & $\begin{array}{l}\text { Participative management \& restoration } \\
\text { of forest degraded landscape of Bessel } \\
\text { Doye Biosphere reserve }\end{array}$ & 3 years & & \\
\hline & & Promotion of community forest in CAR & 3 years & & \\
\hline \multirow[t]{4}{*}{$\mathrm{DRC}$} & \multirow[t]{4}{*}{2010} & $\begin{array}{l}\text { Management and sustainable use of } \\
\text { forest resources }\end{array}$ & $\begin{array}{l}\text { End of } \\
\text { implementation }\end{array}$ & & \\
\hline & & $\begin{array}{l}\text { Initiative of Carbon "Equitable market" } \\
\text { of Sankuru Community }\end{array}$ & $\begin{array}{l}\text { Under } \\
\text { implementation since } \\
2010\end{array}$ & & \\
\hline & & Community agro forestry project & & & \\
\hline & & $\begin{array}{l}\text { Support to the implementation of } \\
\text { community forest }\end{array}$ & & & \\
\hline
\end{tabular}




\begin{tabular}{|c|c|c|c|c|}
\hline & $\begin{array}{l}\text { REDD support to Civil society \& to } \\
\text { government of equator province }\end{array}$ & & & \\
\hline & $\begin{array}{l}\text { Pilot REDD agro forest project } \\
\text { KWAMOUTH South }\end{array}$ & & & \\
\hline & $\begin{array}{l}\text { REDD geographical integrated pilot } \\
\text { project "Eco-Makala" (EU-WWF) }\end{array}$ & $\begin{array}{l}\text { Under } \\
\text { implementation }\end{array}$ & & \\
\hline & $\begin{array}{l}\text { Project to strengthen the national system } \\
\text { of monitoring forest resources for the } \\
\text { promotion of sustainable forest } \\
\text { management and REDD+ in DRC }\end{array}$ & 3 years & & \\
\hline & $\begin{array}{l}\text { Work with communities to reduce } \\
\text { deforestation and poverty in the Vurunga } \\
\text { Hoya region }\end{array}$ & 3 years & & \\
\hline & $\begin{array}{l}\text { Pilot integrated REDD project of } \\
\text { biosphere Luki in Mayombe forest }\end{array}$ & & & \\
\hline & Mombassa pilot REDD project & & & \\
\hline Chad & & & & \\
\hline
\end{tabular}

Source: Donfack (2013) 


\section{Stakeholders participation}

In West Africa, the level of participation of stakeholders and local communities in forest policies and legislation processes and their implementation vary in different countries. There is excessive control on access of local communities to forests resources, hence their limited participation in forest utilization and subsequent management activities. In Gambia for example, as recent as 2006, only 18,000 ha were under community forestry, but now there is an aggressive initiative to promote participatory forest management concept, aimed at transferring 200,000 ha of forest land to local communities by 2019 (Popoola, 2013a).

In Central Africa, involvement of vulnerable groups in policy and legislation and practical forest management seems far from moving from the level of attending meetings to concrete and tangible action in the field. There is a strong consideration of involvement of representatives of indigenous peoples and women associations and schemes and civil society in various country programmes. Women associations suffer from lack of capacity to meaningfully engage in meetings. Reinforcements are being made for community eco development institutions in the forestry sector to be involved in promoting urban forestry, management of native vegetation for rehabilitation of grazing lands and participation of communities in reforestation. Gender mainstreaming into forestry development and climate change work is common. GEF, UNEP and UNDP are providing technical support and funding for REDD+ processes that inculcate multistakeholder participation in forestry and climate change in the region (Donfack, 2013).

Jackson (2004) reported that, though contemporary national policies and legislation are increasingly emphasising community participation in forest management, there is very little evidence of genuine joint and/or collaborative forest management in which power and responsibilities are equitably shared between local communities and PFAs or other designated forest authorities. Thus local community participation is mainly conspicuously stimulated by their involvement in adjacent protected areas and nature reserves, mainly by way of consultative processes to promote exchange of information with local inhabitants on conservation action, and regulated access and use arrangements, in which communities are permitted to harvest forest products following laid down regulations. This is the case in countries such as Cameroon and the Central Africa Republic where Pygmy peoples have so far not benefited equitably from these initiatives although they are known to constitute forest-dependent people and are densely populated adjacent to some protected areas. They are extremely under-represented on local conservation committees; consequently their involvement in regulated access schemes has been very limited.

\section{Measures to increase stakeholder participation}

Recent studies have shown that there is lack of convergence of government, private sector, NGOs, civil society, including women, youth and vulnerable groups in climate change work. These stakeholders work in isolation with minimal impact (Popoola, 2013a; Donfack, 2013; Mvondo, 2012). Multi-stakeholder involvement in forest related climate change work is imperative for success. In addition, there is a strong need for recognition of rights of local communities and indigenous peoples, and their involvement, including through structured participatory processes, to be integral in implementing sustainable forest management, REDD+ 
and participating in MRV programs. A brief overview of some pertinent issues that need urgent attention and that could enhance broad-based stakeholder participation is presented in Tabler 3.

\section{Table 3: Highlights of factors that would improve stakeholder participation in forest- related climate change work in the moist forest countries of Sub-Saharan Africa}

\begin{tabular}{|c|c|}
\hline Region & Factors for enhancing stakeholder participation \\
\hline West Africa (Popoola (2013a) & $\begin{array}{l}\text { - } \begin{array}{l}\text { Development of policies that promotes and acknowledges the } \\
\text { roles of different roles players in public forests administration and } \\
\text { climate change; }\end{array} \\
\text { - Participatory monitoring and implementation of POAs (regional } \\
\text { and local level); } \\
\text { - Surveys for participatory benefit distribution with communities of } \\
\text { carbon incomes; } \\
\text { - Establishment of carbon social projects for income generation in } \\
\text { communities; } \\
\text { - Incentives to increase the development of plantations and } \\
\text { rewarding community forest management activities that increase } \\
\text { timber supply; } \\
\text { - Establishment of forest institutions/forums for knowledge sharing } \\
\text { in order for policy reviews and development of forest projects and } \\
\text { programmes; and } \\
\text { Provision of funding by governments to support REDD+ projects. }\end{array}$ \\
\hline $\begin{array}{l}\text { Central Africa and the Congo Basin } \\
\text { (Donfack (2013) and Mvondo (2012) }\end{array}$ & 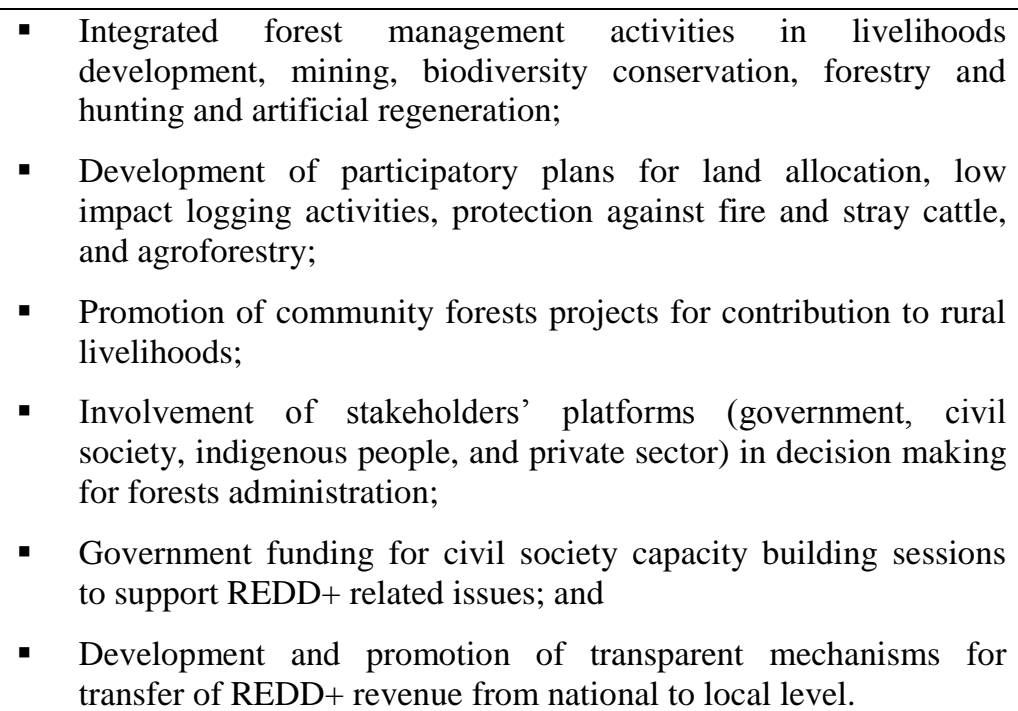 \\
\hline
\end{tabular}




\section{The COMIFAC Guidelines on the Participation of Local Communities and Indigenous Peoples and NGOs in Sustainable Forest Management in Central Africa}

According to Mvondo (2013), the sub-regional guidelines on the participation of local communities and indigenous peoples and NGOs in sustainable forest management in Central Africa adopted in November 2010 by the COMIFAC Council of Ministers serve as a milestone in the regional efforts geared towards improving the rights and welfare of this poor and often vulnerable segment of society. More importantly, the adoption of the guidelines defines the end of the remnants of colonial policy and legal frameworks. Hence the provisions of these innovative guidelines are directly in line with contemporary and emerging mechanisms such as REDD+, FLEGT/VPA and PES, and make a strong emphasis in the recognition of the fundamental rights of the local communities and indigenous peoples. This paradigm shift complies with social claims (of local stakeholders, especially grass-roots activists) and the prerequisites and conditions of major donors such as the World Bank. Mvondo (2013) further stated that success of this model, which seeks to liberate local communities and indigenous people by recognizing their rights to natural resource management and utilization, will largely depend on their implementation and/or quality of their enforcement and the willingness of each member state to comply at the national level, along with the buy-in and ownership of these various rights by the local communities and indigenous people.

\section{Access and equitable benefit sharing}

The valuation of ecosystem services has been at the centre of the United Nations Convention on Biological Diversity which called for the conservation of biological diversity, sustainable use of its components and the fair and equitable sharing of benefits from genetic resource exploitation (UNEP, 1992: AMCEN, 2011).

In West Africa, Popoola (2013a, 2013b) indicated that revised and updated forest policies and legislation in this region seek to develop forest estates and timber industries that provide a full range of benefits for society in an ecologically sustainable manner and conserve the environment and cultural heritage. The limiting factor is the stringent controls on access and harvesting and utilization of forest resources. This has led to exacerbated illegal extraction of forest resources which has in turn had a negative impact on equitable benefit sharing amongst forest stakeholders. However there a great potential with REDD+ which recognizes indigenous and local people.

In Central Africa and the Congo Basin, community forestry and community forests and designated community hunting zones are part of a system of enhancing benefits of local communities and indigenous peoples from forests. However, in the Central African countries, the evaluation of the benefit sharing mechanisms (i.e. distribution of forest taxes, community forestry, etc.) indicated that, in all countries, both the NAMAS and NAPAS do not clearly address the role of forest in their national programmes typically lacking information and/or /knowledge on adaptation to climate change in the forestry sector in many Central Africa countries. However, the intentional involvement of indigenous people in REDD+ processes increases the chances of equitable benefit sharing (Donfack, 2013; Mvondo, 2012). 
It is noteworthy that most countries in West and Central Africa are signatories to the African Charter on Human and Peoples Rights and the Convention 169 of the International Labour Organisation and/or have ratified the Universal Declaration on Human Rights. Similarly, most of the countries are signatories of the United Nations Declaration on Indigenous Peoples' Rights. Hence the need for them to proactively include indigenous populations when designing programmes and projects that directly affect them (Donfack, 2013).

\section{CAPACITY OF PUBLIC FOREST ADMINISTRATIONS IN CLIMATE CHANGE WORK}

\section{Capacities of public forest administrations}

In the late 1990's, Spilbury et. al. (1999) conducted a comprehensive survey of nine forestry institutions in West and Central African countries of Nigeria, Ghana, Cote d'Ivoire, Cameroon, Gabon and Benin to ascertain the capacities for forestry research. These findings form a good basis for PFAs capacities in climate change work in the region. The study indicated that there were a good percentage of well-trained forestry personnel (over 2/3 with MSc and PhD). However, there was insufficient collaborative research and lack of science/policy interface. Furthermore, education and development were poorly coordinated resulting in inadequate flow of information and access to scientific literature. A low level of sustainability for research programme support was noted and the approach to research lacked a multi-sectoral approach. It was concluded that although there was a strong emphasis for the need for capacity building in the region, there was lack of clarity in what could be the most effective strategy and approach. There is therefore more work that needs to be done in conducting precise problem analysis and formulating feasible and effective conceptual frameworks for capacity building in forestry research.

West Africa has the most diverse Public Forest Administrations and forest policies in SSA (Popoola, 2103a). Benin is said to have a good forest policy which is characterized by decentralized forest management, participatory forest management, and accelerated institutional reform in the forestry sector. Burkina Faso's forest policy was guided by its long standing ecological problems. Clearly small-scale forest enterprise and non-timber forest products (NTFPs) are not prioritized. In Cape Verde, forestry is within the Directorate of Agriculture, Forestry and Livestock in the Ministry of Environment and Rural Development and Marine Resources. In Gambia, forestry has undergone significant change and transformation with a new Forest Act and the Forest Policy (2010-2019), and already multiple successes have been reported. Ghana has a Forestry Commission with an innovative forest policy which tackles sustainable forest management issues very well. In Guinea, the Directorate of Waters and Forests is responsible for forestry and this country has a democratic forest policy (i.e. that was developed with full public participation). Cote d'Ivoire is reportedly having an elaborate forest policy that is based on the principles of sustainability. Liberia has a good forest policy and has established a Forestry Development Authority. Mali is said to have a forest law and an adequate forest policy that covers all issues related to forest sector. In Nigeria, the Federal government is in charge of the forest policy whilst implementation rests with State governments. 
In Central Africa and the Congo Basin, the information on exact statistics on Human Resources (HR) capacities and expertise in public forest administrations in the various countries of COMIFAC was difficult to obtain. However, studies by FAO indicate that there are deficiencies and inadequacies in staff and adapting the existing technical expertise in the forestry sector in the region to be relevant to climate change issues. This has most likely been influenced by the effects of the Structural Adjustments Programmes imposed during the 1990s, forcing the postponement of recruitment in public administrations and reduction of States' expenses (Mvondo, 2012).

\section{Adequacies and gaps}

West Africa, like all other Africa regions, has well established public forestry administrations, and its uniqueness is with stringent laws on access to forest resources by local people (Popoola, 2013a, 2013b, Bihibindi, 2013). This region has good forest policies and forest programmes. It has been reported that forest products trans-border trade remains the most efficient, organized and deep-rooted system of trade. However, illegal logging and trade are common in West Africa, and this has negatively impacted the profitability and competitiveness of the forestry sector as an industry. The consequences of illegal logging and related trade may lead to political instability, loss of biodiversity, increased income disparities and market distortions etc. Notwithstanding, this region has by far the lowest deforestation and forest degradation rates, but has actively participated in the REDD preparations.

In Central Africa, PFAs exist in all countries and reforms have been implemented towards sustainable resource use as opposed to the protectionist approach, and forest resources are relatively abundant in the region. However, there were challenges on information availability and gaps. For example, the necessary infrastructure and technology to acquire climate data is not available. Consequently, in order to improve the quality and availability of data from satellite observations of forests and land, the Satellite Observatory for Central Africa (OSFAC) launched the regional network GOFC-GOLD (Global Observation of Forest and Land Cover Dynamics) to support countries in the sub-region. Generally, the number of trained forestry staff is inadequate with very few climate change researchers especially in the forestry sector. Nevertheless, Cameroon plans to design its MRV system and use Terra MODIS images to identify deforestation hotspots. Congo has a significant satellite database. Gabon uses a GIS cell. In DRC the Joint Research Centre and UCL, as well as the University of Maryland and University of South Dakota State monitor the forest cover (Donfack, 2013).

\section{Measures and strategies for improvement}

\section{Human Capacities}

In West Africa, there is generally a lack of human resources in PFAs. For example, the lack of trained professional staff has led to challenges in forest policy implementation with some subsectors within forestry, such as the commercial fuel-cutters and other licensed forest users, lacking supervision. In addition, forestry related climate change work like REDD+ preparations are inadequately capacitated. However, the REDD+ financing mechanisms have a capacity building component (Popoola, 2013; Bihibindi, 2013). 
In Central Africa, there are deficiencies in human expertise in terms of quantity and quality for the feasibility, ownership, design and implementation of the REDD+ mechanisms (Mvondo, 2012). The same challenges exist; sustainable forest management and other climate change adaptation and mitigation activities. Nonetheless, like in East Africa and Southern Africa and other regions of the world, the forestry sector can use climate change expertise from other sectors in the interim.

\section{Financial Capacities}

Financing climate change investments in Africa are done through internationally established initiatives such as CDM, which is a Global Environmental Investment and Credit Scheme that allow compliance trading of certified credits (AMCEN, 2011).

West Africa is faced with low budget allocations to PFAs, which has negative impact on the implementation of national forest policy and associated national forestry programmes and forest plans. The REDD and REDD+ programmes are contributing substantial funding to the development of the forestry sector through international multilateral organizations including the World Bank; with focus on technical infrastructure and governance structures and capacity building (Popoola, 2013a, 2013b).

In Central Africa and the Congo Basin, the limiting factor to sustainable management of natural resources in most countries is inadequate technical and financial capacities (Donfack, 2013). For example, there is no pilot project on climate change in CAR, although there is already a plan of implementation of the gigantic MRV/FAO/COMIFAC programme. The DRC has been externally supported for both the technical and financial aspects of their REDD+ processes. There is general overreliance on donor funding in the region. According to Mvondo (2012), while financial capacities are reported to be lacking, there are positive developments regarding financial opportunities in the COMIFAC countries including the following:

- The World Bank Programme for sustainable forest management in the Congo Basin with funding of US\$40 million between 2010-2014, of which US\$13 million if for REDD;

- The Congo Basin Forest Fund (CBFF) of 2009 for sustainable forest management related projects. This is a joint financing between Great Britain and Norway with a total sum of 120 million Euros managed by the African Development Bank;

- The Forest Carbon Partnership Fund (FCPF) of the World bank for the preparation of policies and strategies for REDD+;

- The Forest Investment Programme finances the implementation of the national REDD strategies developed in the FCPF;

- The sub-regional Programme CARPE of USAID which entered a transitional phase in 2012 with US $\$ 13$ million for activities within the framework of the fight against climate change, with an allocation of US\$17.6 million for the period of 2013-2020; and 
- The new regional initiative to assist 10 Central African countries to set up advanced National Forest Monitoring Systems (MRV). This forestry project will be co-managed by the Central Africa Forests Commission and FAO in collaboration with the Brazilian National Institute for Space Resources (INPE). This initiative will be funded by the Congo Basin Forest Fund launched by the governments of the United Kingdom and Norway through the African Development Bank with a sum of 6.1 million Euros.

\section{Physical Capacities}

AMCEN (2011) advocates for efficient infrastructure and services that is crucial to Africa's regional and sub-regional integration and sustainable development (AMCEN, 2011). It is evident that PFAs in moist forest countries face challenges regarding infrastructure and other equipment and facilities for forest related climate change work. Nonetheless, International development agencies and international research organizations complement their physical capacities. These organizations include the Food and Agriculture Organization on the United Nations (FAO), the United Nations Environment Programme (UNEP), United Nations Development Programme (UNDP), the United Nations Forum on Forests (UNFF), the World Conservation Union (IUCN) and the World Wildlife Fund (WWF). Recently, the African Forest Forum (AFF) and others have generated global databases on forest resources and helped generate research and interventions in sustainable forest management and climate change. In addition, leading international research organizations such as the Centre for International Forestry Research (CIFOR), the International Union Forest Research Organizations (IUFRO), International Institute for Environment and Development (IIED), Centre de Cooperation Internationale en Richerche Agronomique pour le Developpment (CIRAD) and others are heavily involved in global adaptive responding to policy and strategy needs and priorities (AMCEN, 2011; Kakuru, 2013).

\section{Monitoring, reporting and verification (MRV)}

Sound MRV processes are necessary to demonstrate and track implementation of mitigation efforts and also to ensure financial support is being delivered. It also provides an opportunity to showcase tangible mitigation efforts that have been implemented and estimate their contribution to national emissions reductions (AMCEN, 2011).

West Africa, is at the preliminary stages of REDD and REDD+ programmes and as such the PFAs do not have adequate capacities for Monitoring, Verification and Reporting. However, a project was established that seeks to address this shortfall (Popoola, 2013a, 2013b; Bihibindi (2013).

The major MRV Project in the COMIFAC region: Approved in June 2011, at a cost of about EUR 6 million, the Project "Congo Basin MRV Regional Project -Phase I". The overall goal of the project is to support the design and implementation of national monitoring and MRV systems in line with international recommendations and requirements, including coordination and capacity building at regional level. The project will be implemented directly in ten countries of the COMIFAC zone, namely Burundi, Cameroon, Central African Republic, Chad, Congo, Democratic Republic of Congo, Equatorial Guinea, Gabon, Rwanda, and Sao Tome and Principe. The project will benefit the local communities but also the entire world in view of the environmental services provided by the Congo Basin forests (African Development Bank, 2012). 
The expected outcomes at the national level for the countries concerned include: (i) formulation and/or improvement of the legal and institutional framework for REDD + in some countries and; (ii) development and/or improvement of the technical and institutional MRV systems for some countries. The expected outcomes at the regional level include development of the following:

(i) coordination and support activities for forest monitoring and MRV systems,

(ii) arrangements for technical and scientific capacity building and forest monitoring and MRV systems and

(iii) technical support for the national monitoring and MRV systems.

National and regional capacities will be strengthened to formulate forest monitoring and MRV systems action plans particularly through technical assistance from FAO and INPE, in collaboration with other relevant related technical services already operating in the region.

Donfack (2013) noted that in Central Africa and the Congo Basin there was profound lack of trained personnel for the effective implementation of MRV. Thus technical departments in forest management and MRV, climate change and MRV and biodiversity and MRV were perceived to be poor in all countries except for Cameroon. Furthermore, administrative departments in cooperation and program development and administration and finance were also poorly. In most cases forestry staff are trained as forestry engineers, agriculture engineers and technicians. The trend is that there is an exodus of trained personnel owing to very low salaries in the public sector forest administrations.

\section{CONCLUSIONS AND RECOMMENDATIONS}

Traditionally, PFAs have been underfunded yet they carry the mandate of development and implementation of national forest policies, programmes and legislation. New and emerging challenges have resulted in the additional task of adaptation and mitigation to climate change. Since post colonialism times, national governments have been engaged in development, implementation and review of national forest policies and legislation. In addition, there has been participation in development and implementation of regional and international conventions and other forest related agreements, that seek to reshape the forestry sector in a bid to addressing new and emerging challenges. Successes and failures vary between countries within the region. The most notable change is the move towards participatory forestry and managing forests in the context of sustainable development since UNCED Agenda 21 of the maiden environment and development conference held in Rio in 1992.

National governments should collaborate with key stakeholders (local communities, NGOs, the private sector, etc.) in developing and implementing policies and legislation that would prioritize institutional reviews and restructuring of PFAs, increasing funding allocations, capacity building, training and education, for sustainable forest management and climate change adaptation and mitigation and promote sustainable livelihoods. 


\section{ACKNOWLEDGEMENTS}

The authors greatly appreciate the invaluable contribution of the African Forest Forum Team and all authors cited in the text.

\section{REFERENCES}

AFRICAN DEVELOPMENT BANK, 2012. Congo Basin MRV Regional Project - Phase I Multinational Project Appraisal Report February 2012.

AMCEN, 2011. Addressing Climate Change Challenges in Africa: A Practical Guide Towards Sustainable Development.

BIHIBINDI, P.A. 2013. A review of national plans and programmes related to forest and climate change in the Sahel. African Forest Forum (AFF), Nairobi, Kenya.

CBFP (Congo Basin Forest Partnership). 2005. The Forests of the Congo Basin: A Preliminary Assessment. Congo Basin Forest Partneship, Yaoundé, Cameroon.

CBFP (Congo Basin Forest partnership). 2006. The Forests of the Congo Basin, State of the Forest 2006. Congo Basin Forest Partneship, Yaoundé, Cameroon. http://www.giz.de/Themen/de/SID-E1A6CC9F-7E770AE7/dokumente/en-state-of-forests-congobasin-2006.pdf.

DONFACK, P. 2013. National plans and programs related to forest and climate change in Central African countries. African Forest Forum (AFF), Nairobi, Kenya.

DLAMINI, C.S. 2007. Towards the improvement of policy and strategy development for the sustainable management of non-timber forest products: Swaziland: A case study $\mathrm{PhD}$ Dissertation at University of Stellenbosch, South Africa.

DLAMINI, C.S. (2013). A protocol for community-based forest enterprises: the case of nontimber forest products. Journal of Horticulture and Forestry 5(1): 1-12. Available online at http://www.academicjournals.org/JHF.

FAO. 2005. Global Forest Resource Assessment 2005. Available online at www.fao.org/forestry/fra2005

FAO. 2010. Managing forests for climate change: FAO, working with countries to tackle climate change through sustainable forest management. Food and Agricultural Organization (FAO) of the United Nations, Rome, Italy. 
FAO. 2011. State of world's forest. Food and Agricultural Organization (FAO) of the United Nations, Rome, Italy.

FAO. 2012. State of world's forest. Food and Agricultural Organization (FAO) of the United Nations, Rome, Italy.

GEF (Global Environment Facility). 2011. Land, Water, and Forests: Assets for Climate Resilient Development in Africa. Available at: www.theGEF.org.

HASSAN, R.M., MBULI, P. AND DLAMINI, C.S. 2002. Natural resource accounts for the state and economic contribution of forests and woodlands resources in Swaziland. CEEPA Discussion Paper No.4, CEEPA, University of Pretoria, Pretoria. 66p.

JACKSON, D. 2004. Implementation of international commitments on traditional forest related knowledge: Indigenous peoples' experiences in Central Africa. Paper commissioned by the International Alliance of Indigenous and Tribal Peoples of the Tropical Forests for presentation at the Expert Meeting on Traditional Forest-Related Knowledge (TFRK) 6-10 December 2004 in San Jose, Costa Rica.

KAKURU, W. 2013. Review of trade in forest products in the Eastern Africa region. African Forest Forum (AFF), Nairobi, Kenya.

KAMERI-MBOTE, A.P. AND P. CULLET, 1997. Law, Colonialism and Environmental Management in Africa. In Environmental Management in Africa. Volume 6 Issue 1. Blackwell Publishers Ltd. pp. $23-31$.

MVONDO, S.A. 2009. Sustainable Forest Management Practice in Central African States and Customary Law. Internatinal Journal of Sustainable Development and World Ecology Vol. 16, No4: 217-227.

MVONDO, S.A. 2012. An analytical review of forest governance and equitable trade practice related to climate change in Central Africa. African Forest Forum (AFF), Nairobi, Kenya.

MVONDO, S.A. 2103. Local communities' and indigenous people's rights to forests in Central Africa: From hope to challenges. In: Africa Spectrum, 48, 1, 25-47.

OWINO, F. AND NDINGA, A. 2004. Study on forest administration and related institutional arrangements: A report prepared for the project "Lessons learnt on sustainable forest management in Africa". KSLA, AFORNET, and FAO publication.

POPOOLA, L. 2013a. Cross-border trade in forest products and services and trade impacts in West Africa. African Forest Forum (AFF), Nairobi, Kenya. 
POPOOLA, L. 2013b. National and sub-national REDD and REDD+ activities implemented in the Mangroves in West and Central Africa. African Forest Forum (AFF), Nairobi, Kenya.

SPILSBURY, M.J. KOWERO, G.S. AND TCHALA-ABINA, F. 1999. Capacity for Forestry Research in Selected Countries of West and Central Africa. CIFOR, Occasional Paper No. 24.

UNEP, 1992. United Nations Convention on Biodiversity (UN CBD). Available at http://www.unep. org/documents

WILY L.A., 2002. The political economy of community forestry in Africa - Getting the power relations right. Forests, Trees and People Newsletter No. 46:4-12.

WORLD BANK, 2012. Forests, Trees, and Woodlands in AFRICA: An Action Plan for World Bank Engagement. 